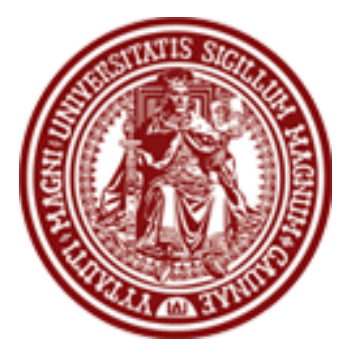

sciendo

\section{BALTIC JOURNAL OF LAW \& POLITICS}

A Journal of Vytautas Magnus University

VOLUME 11, NUMBER 1 (2018)

ISSN 2029-0454
Cit.: Baltic Journal of Law \& Politics 11:1 (2018): 158-186 https://content.sciendo.com/view/journals/bjlp/bjlpoverview.xml

DOI: $10.2478 /$ bjlp-2018-0007

\title{
TOWARDS A PERMANENT CONSULTATION MECHANISM FOR PERSONS WITH DISABILITIES. A STUDY FROM THE PERSPECTIVE OF THE UN CONVENTION ON THE RIGHTS OF PERSONS WITH DISABILITIES
}

\author{
Riku-Heikki Virtanen \\ Ph.D. Candidate in International Law \\ Åbo Akademi University, Institute for Human Rights (Finland) \\ Contact information \\ Address: Vänrikinkatu 3 A, FI-20500 Turku, Finland \\ Phone: +358500234161 \\ E-mail address: riku.virtanen@abo.fi
}

Received: May 21, 2018; reviews: 2; accepted: August 31, 2018.

\begin{abstract}
The Convention on the Rights of Persons with Disabilities (UN CRPD) stipulates an obligation for states to consult persons with disabilities in the development and implementation of legislation and policies with respect of implementing this Convention. Consultations with persons with disabilities have not as yet become a widespread practice in national legal orders. When it comes to EU member states, for example, not all of them incorporate the said obligation in national legislation. In its Concluding Observations the CRPD Committee suggests that the obligation to consult is a cross-cutting duty covering all rights guaranteed in the UN CRPD. Eventually, the draft General Comment No. 7 to the UN CRPD has arrived at a wider interpretation of the scope of an obligation to consult. Although a much wider scope of opportunity to be consulted is provided for the indigenous peoples by the ILO Convention No. 169, it has become a matter of consideration in several cases before
\end{abstract}


regional human rights organs while the convention has not got a significant number of ratifications. Provided that the UN CRPD is much more broadly ratified by the states, will the adoption of this General Comment exert influence on empowering persons with disabilities? In order to find an answer to this question, this article explores the genesis of a general legal obligation to consult persons with disabilities on a permanent basis which would be wider in scope than matters of implementing the UN CRPD in international human rights law.

\section{KEYWORDS}

Persons with disabilities, consultation mechanisms, general principles of law, the obligation to consult, public participation 


\section{INTRODUCTION}

\section{The Issue in Question}

The purpose of this article is to systematize provisions and interpretations concerning an international obligation to consult persons with disabilities. Our main focus is on the concept of the permanent consultation mechanism which is emerging in the interpretations of the Committee on the Rights of Persons with Disabilities (CRPD Committee) and stemming from the provisions of the United Nations Convention on the Rights of Persons with Disabilities (UN CRPD). These interpretations deal with an obligation to consult, based on the provision of Article $4(3)$ of the UN CRPD, which states:

In the development and implementation of legislation and policies to implement the present Convention, and in other decision-making processes concerning issues relating to persons with disabilities, States Parties shall closely consult with and actively involve persons with disabilities, including children with disabilities, through their representative organizations.

As section 3 of this article on jurisprudence of the CRPD Committee shows, the Committee routinely refers to the concept of "consultation mechanism" while addressing the obligation to consult persons with disabilities. However, such a mechanism is not defined in the sources of human rights law. For instance, in its Concluding Observations on Costa Rica the CRPD Committee used the concept of "permanent consultation mechanisms" with respect to an obligation to consult persons with disabilities. The wording of said document states: "The Committee recommends that the State party establish permanent consultation mechanisms with organizations of persons with disabilities, in accordance with article 4, paragraph 3, of the Convention, respecting their autonomy and taking into account the diversity of persons with disabilities, including children and women with disabilities, and the country's indigenous population." ${ }^{1}$

What is this permanent consultation mechanism? In order to gain a comprehensive understanding of it, it is necessary to outline the nature of the obligation to consult persons with disabilities. Therefore, the introductory section explores the historical background of the obligation, and also seeks to posit the obligation to consult on the sources of international law. Then section 2 scrutinizes the relationship between the terms "consultation" and "participation". The similarities and differences between the obligation to consult persons with disabilities and the duty to consult indigenous peoples are introduced briefly. The

$1 C R P D / C / C R I / C O / 1$, Concluding Observation of the UN Committee on the Rights of Persons with Disabilities, para 10. 
article continues with an analysis clarifying the legal interpretations of permanent consultation mechanisms in the jurisprudence of the CRPD Committee. Finally, the author explores theoretical implications of an obligation to consult persons with disabilities with respect to permanent consultation mechanisms, dealing separately with the obligations of states and international development actors. Although country-specific concluding observations refer to the situation in concrete legal orders, they still can be used as a point of reference for examining the Committee's understanding of the scope of Article 4, paragraph 3 of the UN CRPD.

The wording of the UN CRPD's Article 4 as regards the obligation to consult is limited, both ratione personae and ratione materiae. As for the first limitation, such consultations should be held via the representative organizations of persons with disabilities. As for the second limitation, the subject matter of consultations is "the development and implementation of legislation and policies to implement the present Convention" as well as "other decision-making processes concerning issues relating to persons with disabilities." The said limitations explain the further need to explore the potential of establishing a permanent consultation mechanism with respect of persons with disabilities which would be genuine, sustainable, and when it comes to significant decisions to come, also proactive. The Draft General Comment No. 7 to the UN CRPD, the process of adopting which was launched in May 2018 within the CRPD Committee, expressly outlines that "the phrase "concerning issues relating to persons with disabilities", as referred to in article 4.3, must be broadly interpreted to cover the full range of legislative, administrative and other measures that may directly or indirectly affect persons with disabilities". ${ }^{2}$ This Draft stresses the significance of "prior consultations and engagement" with persons with disabilities "at all stages of public decision-making". ${ }^{3}$ The adoption of the said General Comment No. 7 would mean a wider degree of recognition among the state parties to the UN CRPD such that the scope of the said Article 4(3) should be interpreted as a general obligation to consult not tied to the issues of implementing the Convention. In this process "prior consultations and engagement with DPOs/OPDs at all stages of public decision-making, including before the adoption of legislation, policies and programmes that affect them, is a prerequisite."

Notwithstanding the validity of Article 4(3) of the UN CRPD, according to the 2014 report of European Union Agency for Fundamental Rights, not all European Union member states incorporate the obligation to consult persons with disabilities

\footnotetext{
2 Draft General Comment No. 7 - Article 4.3 and 33.3: Participation with Persons with Disabilities in the Implementation and Monitoring of the Convention, UN Committee on the Rights of Persons with Disabilities (16 March 2018) // http://www.ohchr.org/EN/HRBodies/CRPD/Pages/GC.aspx.

3 Ibid., para 19.

${ }^{4}$ Ibid.
} 
"as a requirement or systematic practice" ${ }^{5}$. At the same time, although the practices of EU member states vary significantly, ${ }^{6}$ the culture of consulting persons with disabilities is becoming more common. Therefore, in the light of the opinions of the CRPD Committee, the permanent consulting of persons with disabilities on a wide range of matters related to their rights stipulated by the UN CRPD is evolving towards a recognized general duty to consult of states and even international actors. Although the interpretations of the CRPD Committee regarding permanent consultation mechanisms are still scarce, the author asserts that such mechanisms might have potential in optimizing the implementation of the rights of persons with disabilities under the UN CRPD. As D. G. Newman writes, "the duty to consult obviously contains the seeds of its own future growth".7

\section{Empowering persons with disabilities: a historical overview}

Historically, persons with disabilities have been considered objects but not subjects of law with the full volume of human rights who are equal to others in society. 8 Persons with disabilities had experienced systematic discrimination, 9 which could in certain cases amount to total exclusion from society. For instance, following a traditional medical approach to disability, ${ }^{10}$ persons with disabilities had been seen as patients, and medical professionals assessed the treatments for them. Accordingly, the main purpose was to cure and remove disabilities but not to ensure special rights. According to S. Vehmas et al., the outcome of this medical paternalistic approach is that decisions, which affected persons with disabilities, were made "on behalf of others for their own good, even if contrary to their own wishes". ${ }^{11}$ Although human rights are universal and should apply to all individuals equally, persons with disabilities have been neglected even within the international human rights system. ${ }^{12}$

\footnotetext{
${ }^{5}$ European Union Agency for Fundamental Rights (FRA), The Right to Political Participation for Persons with Disabilities: Human Rights Indicators (Luxembourg: Publications Office of the European Union, 2014), 10.

6 Ibid., 56-57.

7 Dwight G. Newman, Revisiting the Duty to Consult Aboriginal Peoples (Saskatoon: Purich Publishing Limited, 2014), 142.

8 Gerard Quinn and Theresia Degener, Human Rights and Disability. The Current Use and Future Potential of United Nations Human Rights Instruments in the Context of Disability (New York \& Geneva: United Nations, 2002), 9.

9 Rannveig Traustadóttir, "Disability Studies, the Social Model and Legal Developments": 6; in: Oddný Mjöll Arnardóttir and Gerard Quinn, eds., The UN Convention on the Rights of Persons with Disabilities. European and Scandinavian Perspectives (Leiden: Martinus Nijhoff Publishers, 2009).

${ }_{10}$ Ibid.: 5. Steven R. Smith, "Social Justice and Disability. Competing Interpretations of the Medical and Social Models": 15; in: Kristjana Kristiansen, Simo Vehmas, and Tom Shakespeare, eds., Arguing about Disability. Philosophical Perspectives (London and New York: Routledge, 2009).

${ }^{11}$ Simo Vehmas, Kristjana Kristiansen, and Tom Shakespeare, "Introduction: The Unavoidable Alliance of Disability Studies and Philosophy": 3; in: Kristjana Kristiansen, Simo Vehmas, and Tom Shakespeare, eds., Arguing about Disability. Philosophical Perspectives (London and New York: Routledge, 2009).

12 Stein and Lord argued that "Consequently, prior to the adoption of the CRPD, the human rights of persons with disabilities were in theory covered by human rights treaty obligations and addressed in non-binding resolutions and declarations, but in practice were protected by neither" (Michael Ashley
} 
Within the UN, the first ${ }^{13}$ notable documents referring to the need of consultations with persons with disabilities were 1994 CESCR General Comment No. $5^{14}$ and the 1993 Standard Rules on the Equalization of Opportunities for Persons with Disabilities. ${ }^{15}$ Although these documents recognized the rights of persons with disabilities, there was a gap between the reality and theory, ${ }^{16}$ and disability activists began to demand wider rights for persons with disabilities, ${ }^{17}$ and finally in 2001 the UN General Assembly established an Ad Hoc Committee to consider drafting a disability-focused human rights instrument. ${ }^{18}$ In the beginning of negotiations within the Committee a debate arose whether the organizations of persons with disabilities and civil society organizations are allowed to provide their expertise and consultancy on disability-specific issues for the delegates of states preparing the text of the draft convention. ${ }^{19}$ Accordingly, in 2002 a special UN study, entitled "Human Rights and Disability. The Current Use and Future Potential of United Nations Human Rights Instruments in the Context of Disability" highlighted the significance of such consultations arguing that "disability NGOs clearly possess the knowledge but often fail to engage with the human rights system". ${ }^{20}$ After long discussions during the Committee's first and second sessions the expert advice and information provided by disability organizations was accepted and twelve representatives of disability organizations were included in the Working Group which prepared the draft of the Disability Convention, ${ }^{21}$ and the involvement of disability organizations was of the crucial significance during the subsequent

Stein and Janet E. Lord, "Future Prospects for the United Nations Convention on the Rights of Persons with Disabilities": 22; in: Oddný Mjöll Arnardóttir and Gerard Quinn, eds., The UN Convention on the Rights of Persons with Disabilities. European and Scandinavian Perspectives (Leiden: Martinus Nijhoff Publishers, 2009)).

13 Earlier there was an optional provision in Declaration on the Rights of Disabled Persons (United Nations General Assembly, UN Doc. A/RES/3447(XXX) adopted at the 30 th session, 9 December 1975) which mentioned consultations in an Article 12: "Organisations of disabled persons may be usefully consulted in all matters regarding the rights of disabled persons".

${ }^{14}$ General Comment No. 5 - Persons with Disabilities, UN Committee on Economic, Social and Cultural Rights, UN Doc. E/1995/22 adopted at the $11^{\text {th }}$ Session, September 1994, para 14: "In addition, it has been consistently acknowledged by the international community that policymaking and programme implementation in this area should be undertaken on the basis of close consultation with, and involvement of, representative groups of the persons concerned."

15 Standard Rules on the Equalization of Opportunities for Persons with Disabilities, United Nations General Assembly, UN Doc. A/RES/48/96 adopted at the $48^{\text {th }}$ session, 20 December 1993, Rule 21.3: "When planning and reviewing programmes of technical and economic cooperation, special attention should be given to the effects of such programmes on the situation of persons with disabilities. It is of the utmost importance that persons with disabilities and their organizations are consulted on any development projects designed for persons with disabilities. They should be directly involved in the development, implementation and evaluation of such projects."

16 Michael Ashley Stein and Janet E. Lord, supra note 12: 18-19.

17 Maya Sabatello, "A Short History of the Movement"; in: Maya Sabatello and Marianne Schulze, eds., Human Rights and Disability Advocacy (Philadelphia: University of Pennsylvania Press, 2014).

${ }_{18}$ Comprehensive and Integral International Convention to Promote and Protect the Rights and Dignity of Persons with Disabilities, United Nations General Assembly, UN Doc. A/RES/56/168 adopted at the $56^{\text {th }}$ Session, 19 December 2001.

19 Stefan Trömel, "A Personal Perspective on the Drafting History of the United Nations Convention on the Rights of Persons with Disabilities": 117; in: Gerard Quinn and Lisa Waddington, eds., European Yearbook of Disability Law. Volume 1 (Antwerp, Oxford and Portland: Intersentia, 2009).

20 Gerard Quinn and Theresia Degener, supra note 8, 179.

21 Maya Sabatello, supra note 17: 6-7, 23. 
sessions of the Ad Hoc Committee in 2004-2006. ${ }^{22}$ Therefore M. Sabatello argues that the involvement of the organizations of persons with disabilities was at "a new level"23 during the negotiations regarding the UN CRPD. She further argues that the Convention includes "an explicit positive legal obligation on states to seek their [disability organizations - the author] input in all levels of development". ${ }^{24}$ Consequently, the UN CRPD represents a human rights-based approach, and the CRPD Committee has encouraged States Parties to adopt the human rights-based approach instead of the medical approach. ${ }^{25}$

The status of the obligation to consult in the light of Article 38 of the Statute of the International Court of Justice

The UN CRPD has achieved almost universal coverage with the 175 ratifications or accessions to the Convention by March 2018. The UN CRPD is an international human rights treaty among the eight core human rights treaties of the UN. Article 4(3) of the UN CRPD is a treaty-based provision, and it represents a primary source of international law. According to Article 38 of the Statute of the International Court of Justice $(\mathrm{ICJ})^{26}$, the sources of international law consist of international treaties, international custom, general principles and subsidiary sources. Likewise, Vienna Convention on the Law of Treaties ${ }^{27}$ stipulates that the state party which has signed the treaty but not yet ratified it is bound by the object and the purpose of the Convention. ${ }^{28}$ Accordingly, the obligation to consult persons with disabilities is a treaty-based obligation for States Parties of the UN CRPD, and for states which have signed but not yet ratified this Convention, the obligation to consult should have significance in decision-making as promotion, protection and ensuring the full and equal enjoyment of all human rights and fundamental freedoms by all persons with disabilities is among the purposes of the UN CRPD.

However, treaties have impacts with legally binding obligations only to states which had signed or ratified them. In order to avoid a situation that there is no applicable law, general principles of law are applicable. The section 38(1)(c) of the Statute of the ICJ stipulates "the general principles of law recognized by civilized nations". There are two methods for how general principles of law are identified,

\footnotetext{
22 Ibid.

23 Maya Sabatello, supra note 17: 23.

24 Ibid.

$25 \mathrm{CRPD} / \mathrm{C} / \mathrm{ARG} / \mathrm{CO} / 1$, Concluding Observation of the UN Committee on the Rights of Persons with Disabilities, para 50; $C R P D / C / A Z E / C O / 1$, Concluding Observation of the UN Committee on the Rights of Persons with Disabilities, para 50.

26 Statute of the International Court of Justice, T.S. No. 993, adopted 26 June 1945.

27 Vienna Convention on the on the Law of Treaties, Signed at Vienna 23 May 1969.

28 Ibid., Article 18.
} 
namely, hybrid and domestic methods. ${ }^{29}$ With respect to the rights of indigenous peoples, the reasoning of the Inter-American Court of Human Rights was based on the domestic review in Sarayaku v. Ecuador case. ${ }^{30}$ In its 2012 decision the Court argued that the obligation to arrange informed consultation with indigenous peoples concerning state activities that may affect them should be considered a general principle of international law. This decision implies that states should ensure meaningful consultation prior to making decisions potential to affect the rights of indigenous peoples. When it comes to consultation with persons with disabilities, an obligation to arrange them is based on the provisions of the UN CRPD. Moreover, the Standard Rules on the Equalization of Opportunities for Persons with Disabilities $^{31}$ were one of the first UN documents referring to the obligation to consult persons with disabilities. Although these Standard Rules do not contain a specific provision on consultations, they recognize the importance of consulting persons with disabilities. Due to that fact, the obligation to consult persons with disabilities as a general principle of international law is appropriate to build through the hybrid method. According to the hybrid method, the general principle is a valid, autonomous source of law under Article 38(1)(c) of the Statute of the ICJ even if all states do not conform to it in a domestic practice. ${ }^{32}$ As internationally recognized environmental principles, such as sustainable development and precautionary principle, also the obligation to consult persons with disabilities can become an internationally recognized principle, even though not widely identified at domestic legal orders. When the obligation to consult persons with disabilities does not have widespread state recognition at the domestic level, it is not a principle of customary international law. Instead the obligation to consult could evolve and reach a status as a general principle of international law as stated in the section $38(1)$ (c) of the Statute of the ICJ.

\section{A PERMANENT CONSULTATION MECHANISM AS A PARTICIPATORY PROCESS}

Since there is a set of participatory entitlements in the UN CRPD, how does consultation relate to public participation? It is crucial to draw a line between the terms "participation" and "consultation". Under the UN CRPD, a term "consultation" relates to the concept of "an obligation to consult", and its legal basis is the provision of Article 4(3) of the UN CRPD. This concept reflects the view shared by

29 Michelle Biddulph and Dwight Newman, "A Contextualized Account of General Principles of International Law," Pace International Law Review 26(2) (2014): 298-299.

30 Kichwa Indigenous People of Sarayaku v Ecuador, Inter-American Court of Human Rights, June 27, 2012, ser. C, no. 242 // http://corteidh.or.cr/docs/casos/articulos/seriec_245_ing.pdf.

${ }^{31}$ Standard Rules, supra note 15.

32 Michelle Biddulph and Dwight Newman, supra note 29: 313. 
the CRPD Committee and according to which persons with disabilities have the right to be consulted ${ }^{33}$. Article 4(3) aims to ensure that persons with disabilities through their representative organizations are consulted concerning "the development and implementation of legislation and policies"34 in all matters affecting them.

Whereas the term "participation" refers to the right to participate equally with others in civil, political, economic, social and cultural spheres, and, in particular, Article 3(c) on General Principles of the UN CRPD aims at promote the participation of persons with disabilities in society, ${ }^{35}$ Article 29 of this treaty provides for participation in political and public life, and Article 30 provides for participation in cultural life, recreation, leisure and sport. According to M. Stein and J. Lord, participation is both implicit and explicit requirement in the implementation and monitoring mechanisms at national and international levels. ${ }^{36}$ The primary provision of consulting and involving persons with disabilities and their representative organizations ${ }^{37}$ in decision-making processes is linked to different provisions in the Convention, namely, the treaty obliges states parties to include them in monitoring process at the national level, 38 invites states parties to consider consultations with them in the formulation of the member nominations of the CRPD Committee, ${ }^{39}$ and invites states' parties to consider consultations with them in the preparation of reports of states parties. ${ }^{40}$ Consequently, the UN CRPD highlights in an unprecedented way the participation of persons with disabilities through their representative organizations in the development and implementation of legislation and policies. Moreover, participation-related provisions together are "one of the most progressive developments in human rights law provided by the UNCRPD." ${ }^{41}$ In literature, the participation of persons with disabilities ${ }^{42}$ and the monitoring of the

33 CRPD/C/CZE/CO/1, Concluding Observation of the UN Committee on the Rights of Persons with Disabilities, para 16: "... the right of boys and girls with disabilities to be consulted on all matters that affect them".

${ }^{34}$ Article 4(3) of the UN CRPD.

35 Article 3(3) of the UN CRPD. See also the analysis on participation in the context of the UN CRPD in Frédéric Mégret, "The Disabilities Convention: Human Rights of Persons with Disabilities," Human Rights Quarterly 30(2) (2008).

${ }^{36}$ Michael Ashley Stein and Janet E. Lord, "The Committee on the Rights of Persons with Disabilities": section v; in: Philip Alston and Frédéric Mégret, eds., The United Nations and Human Rights. A Critical Appraisal (Oxford University Press, forthcoming 2018).

37 The Article 4(3) of the UN CRPD states "In the development and implementation of legislation and policies to implement the present Convention, and in other decision-making processes concerning issues relating to persons with disabilities, States Parties shall closely consult with and actively involve persons with disabilities, including children with disabilities, through their representative organizations."

38 Article 33(3): "Civil society, in particular persons with disabilities and their representative organizations, shall be involved and participate fully in the monitoring process."

39 Article 34(3): "When nominating their candidates, States Parties are invited to give due consideration to the provision set out in article 4.3 of the present Convention."

40 Article 35(4): "When preparing reports to the Committee, States Parties are invited to consider doing so in an open and transparent process and to give due consideration to the provision set out in article 4.3 of the present Convention."

41 Michael Ashley Stein and Janet E. Lord, supra note 36.

42 Rosemary Kayess and Phillip French, "Out of Darkness into Light? Introducing the Convention on the Rights of Persons with Disabilities," Human Rights Law Review 8(1) (2008). 
UN CRPD ${ }^{43}$ have gained attention. Thematic Study by the Office of the United Nations High Commissioner for Human Rights explains the link between participation and consultations arguing that "full and effective participation and inclusion in society of persons with disabilities is a general principle of the Convention, which also specifically establishes the duty on States to closely consult and actively involve persons with disabilities in the development and implementation of policies that affect them". ${ }^{44}$ Accordingly, participation is a general concept, and consultation is one of its expressions. There is a need for the legal analysis of the obligation to consult and consultation mechanisms regarding persons with disabilities.

With regards to consultation with indigenous peoples, a general obligation to consult is mentioned by Article 6 of ILO Convention No. 169. It says:

In applying the provisions of this Convention, governments shall: (a) consult the peoples concerned, through appropriate procedures and in particular through their representative institutions, whenever consideration is being given to legislative or administrative measures which may affect them directly; (b) establish means by which these peoples can freely participate, to at least the same extent as other sectors of the population, at all levels of decision-making in elective institutions and administrative and other bodies responsible for policies and programmes which concern them; (c) establish means for the full development of these peoples' own institutions and initiatives, and in appropriate cases provide the resources necessary for this purpose. ${ }^{45}$

The duty to consult is relevant also for other vulnerable groups. For instance, in the context of the right of indigenous peoples the prior informed consent as a mode of consultation has emerged as a distinct topic in academic literature and the UN documents. For instance, D. G. Newman elaborates on the duty to consult regarding indigenous peoples in the Canadian practice. ${ }^{46}$ Moreover, a study of the Human Rights Council called Thematic Advice of the Expert Mechanism on the Rights of Indigenous Peoples devotes attention to the duty of states to consult

43 Report by the United Nations Special Rapporteur on Disability on the Question of Monitoring // http://www.un.org/esa/socdev/enable/rights/ahc8docs/ahc8specrep2.doc; Michael Ashley Stein and Janet E. Lord, supra note 36; Michael Ashley Stein and Janet E. Lord, "The United Nations Convention on the Rights of Persons with Disabilities as a Vehicle for Social Transformation"; in: National Monitoring Mechanisms of the Convention on the Rights of Persons with Disabilities (Comision Nacional de los Derechos Humanos de México, Network of the Americas and Office of the United Nations High Commissioner for Human Rights, 2008).

${ }^{44}$ General Comment No. 3 - Article 6: Women and Girls with Disabilities, UN Committee on the Rights of Persons with Disabilities, UN Doc. CRPD/C/GC/3 adopted at the $16^{\text {th }}$ Session, August 2016, para 23.

45 ILO Convention No 169 concerning Indigenous and Tribal Peoples in Independent Countries, 1650 UNTS 383, adopted 27 June 1989, entered into force 5 September 1991.

${ }^{46}$ Dwight G. Newman, supra note 7; Annual Report of the United Nations Special Rapporteur on the Rights and Fundamental Freedoms of Indigenous People, UN Doc. A/HRC/12/34, 15 July 2009; Ben Saul, Indigenous Peoples and Human Rights (Oxford \& Portland: Hart Publishing, 2016), 152-154. 
indigenous peoples. It highlights also that indigenous peoples should be able to determine the result of decision-making processes that affect them. ${ }^{47}$

Article 6 of ILO Convention No. 169 on Indigenous and Tribal Peoples does not merely stipulate a general duty to consult but also mentions the rules, according to which such consultations should be held. Article 6 contains the elements of the free, prior and informed consent (FPIC) principle which defines how consultations on indigenous peoples should be arranged. ${ }^{48}$ The first criterion requires that indigenous peoples can freely take part in decision-making processes affecting them. Second, Article 6 stipulates that consultation should be prior, i.e., proactive with respect of actual decision-making. ${ }^{49}$ Hence, a lack of prior consultations means that legislative and policy measures affecting the indigenous communities would contravene Article 6. For instance, in order to implement the requirement of prior consultations, Norway agreed with the local community of indigenous peoples, the Sami Parliament, a document called Procedures for Consultations between State Authorities and The Sami Parliament in 2005. Norway was the first country that ratified ILO Convention No. 169, and its agreement with indigenous peoples is an example of good practices regarding the implementation the obligation to consult. The objective of the procedures is, inter alia, to "contribute to the implementation in practice of the State's obligations to consult indigenous peoples under international law".

Moreover, Article 6 of ILO Convention No. 169 requires that consultations should be carried out "in good faith and in a form appropriate to the circumstances, with the objective of achieving agreement or consent to the proposed measures". ${ }^{50}$ The most important is the objective of consultations, and the ILO Manual explains "the objective of such consultation is to reach agreement (consensus) or full and informed consent". ${ }^{51}$ Due to these rules, it is possible to make legal assessments whether the measures of state authorities are complying with the rules stipulated in Article 6. Even though a comparable obligation to consult is guaranteed by the ILO Convention No. $169^{52}$ with respect to indigenous peoples, the provision of Article $4(3)$ of the UN CRPD has its own characteristics. On the contrary, Article 4(3) of the UN CRPD stipulates "shall closely consult with and actively involve persons with

\footnotetext{
47 Thematic Advice of the Expert Mechanism on the Rights of Indigenous Peoples. A Compilation (20092013), Office of the United Nations High Commissioner for Human Rights.

48 Parshuram Tamang, An Overview of the Principle of Free, Prior and Informed Consent and Indigenous Peoples in International and Domestic Law and Practices (PFII/2004/WS.2/8, New York: United Nations, 17-19 January 2005).

49 ILO Convention on Indigenous and Tribal Peoples, 1989 (No. 169): A Manual (Geneva: International Labour Office, 2003) // http://www.ilo.org/public/libdoc/ilo/2003/103B09_345_engl.pdf, 15.

50 ILO Convention No 169, supra note 45, Article 6(2).

51 Manual, supra note 49, 16.

52 Article 6(1) states: "In applying the provisions of this Convention, governments shall: (a) consult the peoples concerned, through appropriate procedures and in particular through their representative institutions, whenever consideration is being given to legislative or administrative measures which may affect them directly" (ILO Convention No 169, supra note 45).
} 
disabilities". It is a challenge to perform a legal assessment of whether states are complying with Article 4(3) or not, when the only criterion is to "closely consult". Consequently, unlike Article 6 of ILO Convention No. 169, Article 4(3) of the UN CRPD does not contain an easily measurable criterion for judicial adjudication, such as "objective of achieving agreement or consent" of Article 6 of ILO Convention No. 169. The CRPD Committee has not yet delivered its General Comment No. 7 concerning Article 4 of the UN CRPD, which still remains a draft. In its General Comment No 1 to the UN CRPD, the Committee differentiates "consultation" and "participation" without defining their relationship. ${ }^{53}$ The authoritative interpretation of Article 4 is needed from the CRPD Committee in order to entrench consultation mechanisms within international law as a self-standing participatory mechanism with respect of persons with disabilities which would cover a wide range of issues related to implementation of their rights across all levels and branches of government.

The UN CRPD does not give veto power for persons or organizations participating in consultations. Yet Newman argues that the obligation to consult embodies "an obligation to engage in a good faith process with the genuine objective of obtaining consent". ${ }^{54}$ This implies that consultations can be a pure formality without any real effect in the decision-making process. With regard to development cooperation, G. Quinn argues that "the net effect of Article 32.1(a) is that States Parties have a duty to proof their development aid programmes from the perspective of the rights contained in the Convention". 55 Newman further writes that consultations with Aboriginal peoples have affected major changes and even the cancellations of projects. ${ }^{56}$ However, the powers which a wider interpretation of an obligation to consult gives to the indigenous peoples are at the same time a matter of serious concern for the governments which can be seen in relatively few ratifications of the ILO Convention No. 169. In the case of persons with disabilities, the obligation to consult has already been undertaken by a significantly greater number of the states. This means that a broader interpretation of the scope of this obligation would secure more voice to persons with disabilities in decision-making processes.

\footnotetext{
53 "Those steps must be deliberate, well-planned and include consultation with and meaningful participation of people with disabilities and their organizations" (General Comment No. 1 - Article 12: Equal Recognition Before the Law, UN Committee on the Rights of Persons with Disabilities, UN Doc. CRPD/C/GC/1 adopted at the $11^{\text {th }}$ Session, April 2014, para 30).

54 Dwight G. Newman, supra note 7, 148.

55 Gerard Quinn, "Resisting the 'Temptation Of Elegance': Can the Convention on the Rights of Persons with Disabilities Socialise States to Right Behaviour?": 254; in: Oddný Mjöll Arnardóttir and Gerard Quinn, eds., The UN Convention on the Rights of Persons with Disabilities. European and Scandinavian Perspectives (Leiden: Martinus Nijhoff Publishers, 2009).

56 Dwight G. Newman, supra note 7, 105.
} 
The UN CRPD also includes the concept of a "monitoring mechanism". The monitoring mechanisms are defined in Articles 33 and 34 of the UN CRPD. For the national monitoring mechanisms, the Paris Principles provide a framework for how the mechanism shall be built. ${ }^{57}$ For the international monitoring, Article 34 of the UN CRPD gives the primary guidance. In turn, the concept of the consultation mechanism stems from the understanding of Article 4(3) of the UN CRPD. This mechanism is called a permanent consultation mechanism in the Concluding Observations of the CRPD Committee on Costa Rica ${ }^{58}$. The term "permanent consultation mechanism" has been used by other UN treaty-monitoring bodies before, for instance, in Concluding Observations on Portugal of the Committee on the Rights of the Child. ${ }^{59}$ Although the term is not new, the CRPD Committee has in its Concluding Observations on Costa Rica ${ }^{60}$ referred to the permanent consultation mechanism, and it has developed the permanent consultation mechanism as a tool for the implementation of Article 4(3).

When it comes to persons with disabilities, Article 4(3) on General Obligations of the UN CRPD contains an obligation to consult. Article 4(3) of the UN CRPD, enacting an obligation to consult, covers legislation and policies regarding the rights guaranteed in the Convention, and it vaguely mentions other decision-making processes. Formally, this suggests a lower degree of empowerment in comparison with consultations with indigenous peoples under Article 6 of the ILO Convention No. 169.

In conclusion, a consultation mechanism with respect of persons with disabilities can be seen as a part of a participatory process, which implies seeking for prior and informed consent on the side of the governments in all decisionmaking entailing the rights of persons with disabilities. This process aims to promote the rights of persons with disabilities and their opportunities to participate in society equally with others. As the concept of consultation mechanism comes from the authoritative, quasi-judicial interpretations of the CRPD Committee, these opinions give guidance to states parties for the implementation of the rights guaranteed in the UN CRPD. Specifically, the general comments, country-specific cases, and concluding observations of the CRPD Committee clarify the interpretation of the UN CRPD. Report of the Special Rapporteur on the rights of persons with disabilities summarizes that the CRPD Committee "has highlighted the need to establish formal mechanisms and protocols, at all levels of the government,

\footnotetext{
57 Article 33(2) of the UN CRPD.

$58 \mathrm{CRPD} / \mathrm{C} / \mathrm{CRI} / \mathrm{CO} / 1$, supra note 1 , para 10.

59 Concluding Observations of the Committee on the Rights of the Child: Portugal, UN Doc. CRC/C/15/Add.45, 1995, para 11: "The Committee is concerned by the absence of a permanent consultation mechanism that would permit effective participation by the civil society, in particular nongovernmental organizations (NGOs)".

${ }_{60} \mathrm{CRPD} / \mathrm{C} / \mathrm{CRI} / \mathrm{CO} / 1$, supra note 1 , para 10
} 
to conduct systematic consultations with representative organizations of persons with disabilities. These consultation mechanisms may include institutionalized consultative bodies and other formal mechanisms for direct participation". ${ }^{61}$

\section{CONSULTATIONS WITH PERSONS WITH DISABILITIES: THE INTERPRETATIONS OF THE CRPD COMMITTEE}

Although no special General Comment of the CRPD Committee has as yet been devoted to the issues of participation and consultations, disparate references to these concepts can still be met in its jurisprudence. All these references provided material for the draft General Comment No. 7 to the UN CRPD. Before, the CRPD Committee has referred to Article $4(3)$ of the UN CRPD in several General Comments to this Convention. The terminology in General Comments differs from the language of Concluding Observations. For instance, in General Comment No. 1 the Committee argued, regarding steps towards the realization of the rights provided for in Article 12 of the UN CRPD, that "those steps must be deliberate, well-planned and include consultation with and meaningful participation of people with disabilities and their organizations." ${ }^{2}$ With respect to accessibility standards, in General Comment No. 2 on Accessibility, the terminology of the Committee is as follows: "states parties need to set accessibility standards, which must be adopted in consultation with organizations of persons with disabilities"63 and "minimum standards must be developed in close consultation with persons with disabilities and their representative organizations, in accordance with article 4, paragraph 3, of the Convention". ${ }^{64}$ Moreover, in General Comment No. 3 on Women and girls with disabilities the Committee argues that "states parties must promote the participation of representative organizations of women with disabilities beyond disability-specific consultative bodies and mechanisms". ${ }^{65}$

When the Committee surveyed national practices of implementing the rights set forth by the UN CRPD in its Concluding Observations, the obligation to consult as guaranteed in Article 4(3) of the UN CRPD was addressed on a considerable number of occasions. The Committee encouraged States parties to consult with organizations of persons with disabilities concerning implementation of many Articles of the UN CRPD. We are looking for a generalized framework in approaching the following issues in the jurisprudence of the CRPD Committee. First, what is the

\footnotetext{
${ }^{61}$ Report of the Special Rapporteur on the Rights of Persons with Disabilities on the Right of Persons with Disabilities to Participate in Decision-Making, UN Doc. A/HRC/31/62 12, January 2016, para 66.

62 General Comment No. 1, supra note 53, para 30.

63 General Comment No. 2 - Article 9: Accessibility, UN Committee on the Rights of Persons with Disabilities, UN Doc. CRPD/C/GC/2 adopted at the 11th session, April 2014, para 25.

${ }^{64}$ Ibid., para 30.

65 General Comment No. 3, supra note 44, para 23.
} 
exact legal meaning of the obligation to consult, namely, should the consultations be carried out or not? Then, what are the parties of consultations? Moreover, what are the procedural requirements of the permanent consultation mechanisms?

The Committee has most frequently referred to the obligation to consult in its Concluding Observations in connection with the rights of women and children with disabilities. Concerning Article 6 of the UN CRPD, the Committee in its Concluding Observations urged Mongolia 66 to consult women with disabilities and their representative organizations. With regards to Article 7, in Concluding Observations on Czech Republic, the Committee urged that state "to adopt safeguards [permanent consultation mechanisms - the author] to protect the right of boys and girls with disabilities to be consulted on all matters that affect them". 67 In brief, the Committee has underscored the significance of the right to be consulted when it has recommended states parties, inter alia, to put in place (Mexico) ${ }^{68}$ or adopt (Belgium) ${ }^{69}$ safeguards, implement measures (Kenya) ${ }^{70}$, ensure (European Union) ${ }^{71}$ existing safeguards and adopt additional ones (Sweden) ${ }^{72}$ to protect the right to consult children with disabilities and their representative organizations.

When the Committee reviewed substantive articles of the UN CRPD and referred to the obligation to consult it uses in most cases such phrases as "recommends" and "encourages". For instance, concerning Article 8, the Committee has encouraged Denmark ${ }^{73}$ and recommended Belgium ${ }^{74}$ to set up awareness raising activities, ${ }^{75}$ inter alia, by promoting a positive image of persons with disabilities, their rights and their contributions to society ${ }^{76}$, in consultation with the organizations of persons with disabilities. In addition, the expression is slightly stronger regarding State Reports. Concerning Article 35 on Reports by States

66 CRPD/C/MNG/CO/1, Concluding Observation of the UN Committee on the Rights of Persons with Disabilities, para 11.

67 CRPD/C/CZE/CO/1, supra note 33, para 16.

$68 C R P D / C / M E X / C O / 1$, Concluding Observation of the UN Committee on the Rights of Persons with Disabilities, para 16.

$69 C R P D / C / B E L / C O / 1$, Concluding Observation of the UN Committee on the Rights of Persons with Disabilities, para 16. See also CRPD/C/BRA/CO/1, Concluding Observation of the UN Committee on the Rights of Persons with Disabilities, para 19; CRPD/C/HRV/CO/1, Concluding Observation of the UN Committee on the Rights of Persons with Disabilities, para $12 ; C R P D / C / D E U / C O / 1$, Concluding Observation of the UN Committee on the Rights of Persons with Disabilities, para 18; CRPD/C/MNG/CO/1, supra note 66, para 13.

$70 \mathrm{CRPD} / \mathrm{C} / \mathrm{KEN} / \mathrm{CO} / 1$, Concluding Observation of the UN Committee on the Rights of Persons with Disabilities, para 14.

$71 C R P D / C / E U / C O / 1$, Concluding Observation of the UN Committee on the Rights of Persons with Disabilities, para 25.

72 CRPD/C/SWE/CO/1, Concluding Observation of the UN Committee on the Rights of Persons with Disabilities, para 20.

$73 C R P D / C / D N K / C O / 1$, Concluding Observation of the UN Committee on the Rights of Persons with Disabilities, para 23.

$74 C R P D / C / B E L / C O / 1$, para 18. See also $C R P D / C / D E U / C O / 1$, para 20;CRPD/C/KEN/CO/1, para 16; CRPD/C/SWE/CO/1, para 22.

75 Article 9 of the UN CRPD.

$76 C R P D / C / G A B / C O / 1$, Concluding Observation of the UN Committee on the Rights of Persons with Disabilities, para 21. 
parties $^{77}$, in its Concluding Observations on Austria, the Committee has strongly encouraged Austria to consult the organizations of persons with disabilities while they will prepare their next periodic reports. ${ }^{78}$

In some cases, the Committee used stronger expressions. For instance, in Concluding Observations on Austria, the Committee uses the strong expression "should" with respect of awareness raising campaigns, saying that the state party "should, in consultation with disabled persons' organizations, take specific measures, including awareness-raising campaigns, aimed at eliminating prejudices". ${ }^{79}$ In a similar manner, in Concluding Observations on Croatia, the Committee argued that "Organizations of persons with disabilities should be involved in planning and implementing the accessibility plans". ${ }^{80}$ Likewise, relating to Article 27 on Employment, ${ }^{81}$ the Committee argued that Mauritius "should extend affirmative actions to the public sector and monitor compliance, establish programmes to facilitate the inclusion of young persons with disabilities in the open labour market, in close consultation with organizations of persons with disabilities". 82 Furthermore, concerning Article 11 on situations of risk and humanitarian emergencies, the Committee has called upon Australia "to consult with people with disabilities to establish nationally consistent emergency management standards". 83 Moreover, concerning Article 33 on National monitoring ${ }^{84}$, in its Concluding Observations on Costa Rica, the Committee called on the State Party "to consult with disabled persons' organizations in creating or designating focal points for implementing the Convention". ${ }^{85}$

The Committee referred to the parties of consultations in its Concluding Observations. Concerning Article 32 devoted to International cooperation, ${ }^{86}$ the Committee recommended that Gabon ensure that the implementation of the post2015 development framework (Sustainable Development Goals) is fully inclusive of persons with disabilities, and that organizations of persons with disabilities are systematically consulted by the State party and international development actors. ${ }^{87}$

\footnotetext{
77 Article 35 of the UN CRPD.

$78 C R P D / C / A U T / C O / 1$, Concluding Observation of the UN Committee on the Rights of Persons with Disabilities, para 61 . See also $C R P D / C / A Z E / C O / 1$, supra note 25 , para 55 ; $C R P D / C / B R A / C O / 1$, supra note 69 , para 63.

79 CRPD/C/AUT/CO/1, supra note 78, para 22.

$80 \mathrm{CRPD} / \mathrm{C} / \mathrm{HRV} / \mathrm{CO} / 1$, supra note 69 , para 16.

${ }^{81}$ Article 27 of the UN CRPD.

82 CRPD/C/MUS/CO/1, Concluding Observation of the UN Committee on the Rights of Persons with Disabilities, para 38.

83 CRPD/C/AUS/CO/1, Concluding Observation of the UN Committee on the Rights of Persons with Disabilities, para 23.

${ }^{84}$ Article 33 of the UN CRPD.

${ }^{85} \mathrm{CRPD} / \mathrm{C} / \mathrm{CRI} / \mathrm{CO} / 1$, supra note 1 , para 66.

${ }^{86}$ Article 32 of the UN CRPD.

$87 C R P D / C / G A B / C O / 1$, supra note 76, para 69. See also $C R P D / C / K E N / C O / 1$, supra note 70, para 58.
} 
With respect to the procedural requirements for consultation mechanisms, Concluding Observations of the CRPD Committee include a number of different references. First, the Committee is of the opinion that States parties should take effective steps in order to respect the autonomy of persons with disabilities taking into account the diversity ${ }^{88}$ of persons with disabilities. Second, according to the Committee, consultations should be systematic, regular ${ }^{89}$ and ongoing. ${ }^{90}$ Third, according to the Committee, consultations should be legally recognized as obligations de jure nature ${ }^{91}$. Fourth, the Committee establishes that consultations should be carried out a meaningful, 92 proper ${ }^{93}$ and appropriate way with a transparent ${ }^{94}$ and better-documented mechanism ${ }^{95}$ which allows reasonable and realistic timelines for providing the views of persons with disabilities. ${ }^{96}$ Fifth, the Committee defines that States parties should ensure adequate, 97 sufficient, independent and continuous financial resources 98 for consultations. All these observations support our earlier assertion that Article 4(3) of the UN CRPD has a potential to evolve into the overwhelming practice of permanent consultation mechanisms.

The Concluding Observations on the interpretation of the rights of persons with disabilities have "enormous potential to influence national laws and policies". ${ }^{99}$ In the context of disability, consultations may offer valuable information which enables decision-makers, at local, national and international levels, to create and maintain disability-friendly policies and services.

The analyzed materials show that the CRPD Committee considers the obligation to consult to be one of the cross-cutting principles in the UN CRPD. In Concluding Observations, the references to consultations can be divided in two categories. First, the Committee refers to Article 4(3) when encouraging states to implement the rights of persons with disabilities in consultation with the representative organizations of persons with disabilities. Second, the Committee refers to general principles and obligations of the UN CRPD in its Concluding

${ }^{88}$ CRPD/C/CRI/CO/1, supra note 1 , para 10.

${ }^{89} C R P D / C / T K M / C O / 1$, Concluding Observation of the UN Committee on the Rights of Persons with Disabilities, para $8 ; C R P D / C / M E X / C O / 1$, supra note 68 , para $8 ; C R P D / C / M U S / C O / 1$, supra note 82 , para 6.

90 CRPD/C/PRY/CO/1, Concluding Observation of the UN Committee on the Rights of Persons with Disabilities, para 10.

${ }_{91}$ CRPD/C/UKR/CO/1, Concluding Observation of the UN Committee on the Rights of Persons with Disabilities, para 61.

${ }_{92} C R P D / C / E U / C O / 1$, supra note 71 , para $15 ; C R P D / C / M U S / C O / 1$, supra note 82 , para 6.

${ }^{93} C R P D / C / M E X / C O / 1$, supra note 68 , para 8.

${ }^{94}$ CRPD/C/MUS/CO/1, supra note 82 , para 6.

${ }^{95} \mathrm{CRPD} / \mathrm{C} / \mathrm{TKM} / \mathrm{CO} / 1$, supra note 89 , para 8.

${ }^{96}$ CRPD/C/HUN/CO/1, Concluding Observation of the UN Committee on the Rights of Persons with Disabilities.

${ }^{77} C R P D / C / B E L / C O / 1$, supra note 69 , para 10.

${ }_{98} C R P D / C / G A B / C O / 1$, supra note 76 , para 9.

${ }^{99}$ Christina Zampas and Jaime M. Gher, "Abortion as a Human Right-International and Regional Standards," Human Rights Law Review 8(2) (2008): 253. 
Observations, and these references bring guidance for states parties on how consultations should be implemented through formal consultation mechanisms on a wide range of matters affecting persons with disabilities.

\section{TOWARDS A PERMANENT CONSULTATION MECHANISM?}

A concept of permanent consultation mechanism as developed in the interpretations of the CRPD Committee can be seen as a means the primary objective of which is to involve the representatives of persons with disabilities in decision-making in order to fully implement all the rights of the latter. This means is implemented via institutional machinery serving the end of implementing states' human rights obligations.

In $1980 \mathrm{H}$. Shue published a first version of the tripartite typology of state duties. In Shue's typology, states are obliged to avoid depriving, protect deprived and provide aid. ${ }^{100}$ Later A. Eide published a modified version of Shue's tripartite typology. ${ }^{101}$ According to Eide, states have obligations to respect, protect, and fulfil human rights. Legal scholars have further developed the typology of state duties after Shue and Eide. P. Alston and H. Steiner differentiate five levels of state duties. ${ }^{102}$ Their duties include (1) respect rights of others (2) create institutional machinery essential to realization of rights (3) protect rights/prevent violations (4) provide goods and services to satisfy rights and (5) promote rights. ${ }^{103}$ Alston and Steiner argued that the duty to create institutional machinery essential to realization of rights requires, for instance, that states allocate public funds in order to create an institutional machinery, such as an electoral machinery. ${ }^{104}$ Likewise, Shue proposed a slightly similar duty as Alston and Steiner while he wrote about "the duty to protect by building adequate institutions". 105 The duty to design institutions is a sub-duty with respect to an obligation to protect. However, the duty to create the institutional machinery as understood by Alston and Steiner is independent duty consistent with the recent developments in international human rights law "which have made it clear that human rights require States to create and establish institutional machinery". 106 The permanent consultation mechanisms

\footnotetext{
100 Henry Shue, Basic rights. Subsistence, Affluence, and U.S. Foreign Policy (Princeton \& New Jersey: Princeton University Press, 1980).

101 Asbjørn Eide, "The International Human Rights System": 154; in: Asbjørn Eide, Wenche Barth Eide, Susantha Goonatilake, Joan Gussow, and Omawale, eds., Food as a human right (Tokyo: United Nations University, 1984).

102 Henry J. Steiner, Philip Alston, and Ryan Goodman, International Human Rights in Context. Law, Politics, Morals, $3^{\text {rd }}$ edition (New York: Oxford University Press, 2007), 186-189.

103 Ibid.

104 Ibid., 188.

105 Henry Shue, "The Interdependence of Duties": 94; in: Philip Alston and Katarina Tomaševski, eds., The Right to Food (Utrecht: Martinus Nijhoff Publishers, 1984).

106 M. Magdalena Sepúlveda, The Nature of the Obligations under the International Covenant on Economic, Social and Cultural rights (Antwerpen: Intersentia, 2003), 168.
} 
mentioned in the jurisprudence of the CRPD Committee can be seen as one form of the institutional machinery by Steiner and Alston. Notwithstanding, creating and maintaining institutional machineries essential to realization of rights is not a costfree duty of states. Allocating funding for consultation mechanism is a positive measure, and the CRPD Committee has recommended states to allocate resources for consultations. ${ }^{107}$

The CRPD Committee has used the terminology of state duties in its jurisprudence regarding consultation mechanisms. In Concluding Observations on Czech Republic, there is a comment showing that states parties have the obligation to protect the right of children be consulted. ${ }^{108}$ Likewise, the Committee recommended "that the European Union ensure that boys and girls with disabilities and their representative organisations be consulted". 109 Due to the small amount of references, it is hard to say whether it is a coincidence or are there references to obligation to protect and obligation to fulfil (ensure). Although the wording varies, the interpretation of the CRPD Committee implies that the Convention obliges states parties to establish and maintain safeguards which guarantee that children with disabilities will be consulted. In this context, these safeguards probably refer to permanent consultation mechanisms. Indeed, the obligation to consult consists of an individual and collective safeguards. In the context of a decision affecting to an individual child, decision-makers are obliged to ensure that the child will be consulted. Whereas in the planning and implementation of legislation or policies affecting to children, states are obliged to ensure that the representatives of children with disabilities are consulted through a consultation mechanism.

Concrete means by virtue of which states implement their obligations stemming from international treaties such as the UN CRPD vary significantly. Ultimately, although decision-makers would accept the duty to establish and maintain permanent consultation mechanisms, the implementation depends on values and priorities. As A. Sen argues, "our opportunities and prospects depend crucially on what institutions exist and how they function". ${ }^{110}$ In practice, a permanent consultation mechanism either does not exist or it is merely ad hoc based in the light of the submissions to the CRPD Committee by non-governmental organizations ${ }^{111}$. Despite this fact, the CRPD Committee has emphasized the

\footnotetext{
107 CRPD/C/GAB/CO/1, supra note 76 , para 9.

$108 C R P D / C / C Z E / C O / 1$, supra note 33, para 16.

109 CRPD/C/EU/CO/1, supra note 71, para 25.

110 Amartya Sen, Development as Freedom (New York: Oxford University Press, 2001), 142.

111 Submission to the CRPD Committee on the List of issues in relation to the initial report of Croatia, Croatian Union of Associations of Persons with Disabilities and other contributing DPOs (March 2015) // http://tbinternet.ohchr.org/Treaties/CRPD/Shared\%20Documents/CRO/INT_CRPD_CSS_CRO_19930_E.d oc; Shadow Report for the Review of the State of Chile before the Committee on the Rights of Persons with Disabilities in the $15^{\text {th }}$ Session, Corporación Circulo Emancipador de Mujeres y Niñas con Discapacidad de Chile et al. (March 2016) //
} 
necessity "to establish formal mechanisms $\ldots$ to conduct systematic consultations". ${ }^{112}$ The term "formal mechanism" can be considered to refer to a permanent, not ad hoc mechanism. Consequently, although there are conceptual frameworks for state duties and a transnational duty, the implementation of consultation mechanisms depends on states and international actors.

\section{THE OBLIGATIONS OF INTERNATIONAL DEVELOPMENT ACTORS WITH RESPECT TO PERMANENT CONSULTATION MECHANISMS}

The question also arises with respect to international actors and their obligation to consult. States parties to the UN CRPD are primarily under an obligation to abide by the Convention. The UN CRPD is open for signatories "by all States and by regional integration organizations". ${ }^{113}$ The wording covers states and regional integration institutions, such as the European Union. Concerning the obligation to consult, the CRPD Committee, however, recommended in Concluding Observations on Gabon ${ }^{114}$ that the State party ensure the organizations of persons with disabilities are "consulted by the State Party and international development actors". ${ }^{115}$ This formulation could imply that the responsibility to do active steps applies to the state party even in the situations where the consulting actor is an international development organization. Another, more likely interpretation is that other actors as only states parties have obligations concerning human rights, including the obligation to consult persons with disabilities while their activities are affecting persons with disabilities.

The jurisprudence of the CRPD Committee includes recommendations on consultations concerning both national authorities and international development actors. ${ }^{116}$ The CRPD Committee has argued that States parties are responsible for

http://tbinternet.ohchr.org/Treaties/CRPD/Shared\%20Documents/CHL/INT_CRPD_CSS_CHL_23091_E.p df; Submission to the CRPD Committee on the List of issues in relation to the initial report of European Union, European Disability Forum (July 2015) //

http://tbinternet.ohchr.org/Treaties/CRPD/Shared\%20Documents/EUR/INT_CRPD_CSS_EUR_21276_E.d oc; Submission to the CRPD Committee on the List of issues in relation to the initial report of Kenya, Disabled People's Organizations in Kenya (June 2015) //

http://tbinternet.ohchr.org/Treaties/CRPD/Shared\%20Documents/KEN/INT_CRPD_CSS_KEN_21296_E.d ocx; Submission to the CRPD Committee on the List of issues in relation to the initial report of Italy, Italian Disability Forum (19 July 2016) //

http://tbinternet.ohchr.org/Treaties/CRPD/Shared\%20Documents/ITA/INT_CRPD_CSS_ITA_24625_E.do C; Submission to the CRPD Committee on the List of issues in relation to the initial report of the Czech Republic, Czech NGOs and DPOs //

http://tbinternet.ohchr.org/Treaties/CRPD/Shared\%20Documents/CZE/INT_CRPD_CSS_CZE_19782_E.p df; Submission to the CRPD Committee on the List of issues in relation to the initial report of Sweden, Swedish Disability Federation //

http://tbinternet.ohchr.org/Treaties/CRPD/Shared\%20Documents/SWE/INT_CRPD_NGO_SWE_16818_E. doc.

112 Report of the Special Rapporteur, supra note 61, para 66.

113 Article 42 of the UN CRPD.

$114 C R P D / C / G A B / C O / 1$, supra note 76 , para 69.

115 Ibid.

116 Ibid. 
the activities carried out at their territory, or in partnership with them ${ }^{117}$ within international cooperation. Hence, in situations where, inter alia, States parties are funding or carrying out international cooperation projects, States parties are obliged to respect the rights of persons with disabilities outside their territory. ${ }^{118}$

With respect to international development actors, S. Skogly argues that the World Bank and the International Monetary Fund, which are one of the biggest international development actors, have the obligation to respect human rights. ${ }^{119}$ Skogly ${ }^{120}$ argues further that these institutions have more limited obligations than states parties, and, according to Skogly, the institutions do not have the obligation to fulfil human rights. ${ }^{121}$ However, A. Clapham argues that international financial institutions have obligations to respect, "protect and even fulfil human rights in appropriate circumstances". ${ }^{122}$ Afterwards I. Koch comments that different levels of typologies are overlapping. ${ }^{123}$ Although state duties relate to both, national and international activities of the states, institutional duties can be performed also by international actors. Shue introduces the so-called "transnational duty" to build institutions, when he wrote about failures in activities of intergovernmental organizations and state-to-state foreign aid. ${ }^{124}$ Although states are seen as obligation-holders in international human rights law, Shue argues that international development actors, such as the World Bank, have transnational duties. ${ }^{125}$ In the context of the rights of persons with disabilities, the transnational duty gives a conceptual framework for a debate whether financial institutions have an obligation to consult persons with disabilities or not.

In the context of this article, it should be asked whether international development actors, such as the World Bank and the IMF, have transnational duties as Shue asserts, or even the obligation to create institutional machinery essential to realization of rights as Steiner and Alston argue concerning state duties. ${ }^{126}$ The wording of Article 32 of the UN CRPD "in partnership with relevant international and regional organizations" supports the interpretation that states parties are primarily

$117 C R P D / C / A Z E / C O / 1$, supra note 25 , para $51 ; C R P D / C / T U N / C O / 1$, Concluding Observation of the UN Committee on the Rights of Persons with Disabilities, para 40.

118 Tahmina Karimova, Human Rights and Development in International Law (London \& New York: Routledge, 2016), 218.

119 Sigrun I. Skogly, The Human Rights Obligations of the World Bank and the International Monetary Fund (London: Cavendish Publishing Limited, 2001), 193.

120 Ibid.

121 Ibid.

122 Andrew Clapham, Human Rights Obligations of Non-State Actors (New York: Oxford University Press, 2006), 151.

${ }^{123}$ Ida Elisabeth Koch, "Dichotomies, Trichotomies or Waves of Duties?" Human Rights Law Review 5(1) (2005): 91.

124 Henry Shue, supra note 105: 93: "Some of the duties are, then, what would traditionally have been called universal duties and what we might now more naturally call transnational duties. This is clear from the responsibility to take due care toward vulnerable whom one may affect".

125 Ibid.

126 Henry J. Steiner, Philip Alston, and Ryan Goodman, supra note 102, 186-189. 
responsible for the implementation of the UN CRPD, and other actors are acting in partnership with state parties within international cooperation. However, Skogly argues that the financial institutions "will have shared responsibility with the governments with whom they co-operate". ${ }^{127}$ Stein goes further and argues that "they bear their own share of responsibility". ${ }^{128}$ However, it is worth noting that these responsibilities of international development actors apply to the activities which they are involved in. Indeed, they have, at least a moral, if not legal obligation to consult persons with disabilities who are affected by projects and programmes. In order to implement their own share of responsibility, the financial institutions need disability-inclusive policies. ${ }^{129}$

\section{CONCLUSIONS}

The wording of Article 4(3) of the UN CRPD, stipulating an obligation to consult persons with disabilities on "development and implementation of legislation and policies to implement the present Convention, and in other decision-making processes" represents a material limitation to the scope of the obligation to consult. The analysis of the jurisprudence of the CRPD Committee shows that the CRPD Committee through the overview of national practices encourages states parties to the UN CRPD to establish permanent consultation mechanisms in order to consult persons with disabilities and their representative organizations in all matters affecting them, not only on the matters of implementing the UN CRPD. Therefore, this article studied the conceptual background of the evolving trend in international human rights law towards a wider interpretation of an obligation to consult persons with disabilities on a permanent basis seeking for their prior and informed consent in all matters related to their rights under the UN CRPD.

Although there is no recognized general principle of international law which would oblige the states to consult persons with disabilities through permanent consultation mechanisms, such an obligation has strong chances to be elaborated further. Such recognition could be made by adopting the draft General Comment No. 7 to the UN CRPD regarding an obligation to consult which would trigger national practices in this sphere.

Article 6 of ILO Convention No. 169 contains more specific guidance on the implementation of consultations than Article 4(3) of the UN CRPD. However, unlike the UN CRPD with almost universal ratification, only a limited number of states

127 Sigrun I. Skogly, supra note 119, 193.

128 Michael Ashley Stein and Penelope J. S. Stein, "Disability, Development, and Human Rights: A Mandate and Framework for International Financial Institutions," UC Davis Law Review 47 (2014): 1250. 129 Ibid.: $1260-1263$. 
have ratified ILO Convention No. 169. ${ }^{130}$ It has been suggested that many European countries are reluctant to adopt the rights of indigenous peoples in their national legislations, and instead they prefer a minority rights-based approach. ${ }^{131}$ Although according to interpretations based on the said Articles, both require, inter alia, prior consultations, Article 4(3) of the UN CRPD offers more vague guidance than Article 6 of ILO Convention No. 169 to the judicial adjudication. In spite of less specific language in Article 4(3) of the UN CRPD, the CRPD Committee gradually widened the scope of the obligation to consult persons with disabilities, and evolved the concept of the permanent consultation mechanism in its jurisprudence. Moreover, the interpretations of the CRPD Committee on the obligation to consult persons with disabilities through a permanent consultation mechanism can be considered to apply also to the obligations of international development actors.

\section{BIBLIOGRAPHY}

1. Biddulph, Michelle, and Dwight Newman. "A Contextualized Account of General Principles of International Law." Pace International Law Review 26(2) (2014): 286-344.

2. Clapham, Andrew. Human Rights Obligations of Non-State Actors. New York: Oxford University Press, 2006.

3. Eide, Asbjørn. "The International Human Rights System": 152-161. In: Asbjørn Eide, Wenche Barth Eide, Susantha Goonatilake, Joan Gussow, and Omawale, eds. Food as a human right. Tokyo: United Nations University, 1984.

4. Errico, Stefania, and Barbara Ann Hocking. "Reparations for Indigenous Peoples in Europe: The Case of the Sámi People": 363-388. In: Federico Lenzerini, ed. Reparations for Indigenous Peoples. International \& Comparative Perspectives. Oxford: Oxford University Press, 2008.

5. European Union Agency for Fundamental Rights (FRA). The Right to Political Participation for Persons with Disabilities: Human Rights Indicators. Luxembourg: Publications Office of the European Union, 2014.

6. ILO Convention on Indigenous and Tribal Peoples, 1989 (No.169): A Manual. Geneva: International Labour Office, 2003 // http://www.ilo.org/public/libdoc/ilo/2003/103B09_345_engl.pdf.

7. Karimova, Tahmina. Human Rights and Development in International Law. London \& New York: Routledge, 2016.

130 Dwight G. Newman, supra note 7, 144.

131 Stefania Errico and Barbara Ann Hocking, "Reparations for Indigenous Peoples in Europe: The Case of the Sámi People": 365; in: Federico Lenzerini, ed., Reparations for Indigenous Peoples. International \& Comparative Perspectives (Oxford: Oxford University Press, 2008). 
8. Kayess, Rosemary, and Phillip French. "Out of Darkness into Light? Introducing the Convention on the Rights of Persons with Disabilities." Human Rights Law Review 8(1) (2008): 1-34.

9. Koch, Ida Elisabeth. "Dichotomies, Trichotomies or Waves of Duties?" Human Rights Law Review 5(1) (2005): 81-103.

10. Mégret, Frédéric. "The Disabilities Convention: Human Rights of Persons with Disabilities." Human Rights Quarterly 30 (2) (2008): 494-516.

11. Newman, Dwight G. Revisiting the Duty to Consult Aboriginal Peoples. Saskatoon: Purich Publishing Limited, 2014.

12. Quinn, Gerard, and Theresia Degener. Human Rights and Disability. The Current Use and Future Potential of United Nations Human Rights Instruments in the Context of Disability. New York \& Geneva: United Nations, 2002.

13. Quinn, Gerard. "Resisting the 'Temptation Of Elegance': Can the Convention on the Rights of Persons with Disabilities Socialise States to Right Behaviour?": 215-256. In: Oddný Mjöll Arnardóttir and Gerard Quinn, eds. The UN Convention on the Rights of Persons with Disabilities. European and Scandinavian Perspectives. Leiden: Martinus Nijhoff Publishers, 2009.

14. Sabatello, Maya. "A Short History of the Movement": 13-24. In: Maya Sabatello and Marianne Schulze, eds. Human Rights and Disability Advocacy. Philadelphia: University of Pennsylvania Press, 2014.

15. Saul, Ben. Indigenous Peoples and Human Rights. Oxford \& Portland: Hart Publishing, 2016.

16. Sen, Amartya. Development as Freedom. New York: Oxford University Press, 2001.

17. Sepúlveda, M. Magdalena. The Nature of the Obligations under the International Covenant on Economic, Social and Cultural rights. Antwerpen: Intersentia, 2003.

18. Shue, Henry. "The Interdependence of Duties": 83-95. In: Philip Alston and Katarina Tomaševski, eds. The Right to Food. Utrecht: Martinus Nijhoff Publishers, 1984.

19. Shue, Henry. Basic rights. Subsistence, Affluence, and U.S. Foreign Policy. Princeton \& New Jersey: Princeton University Press, 1980.

20. Skogly, Sigrun I. The Human Rights Obligations of the World Bank and the International Monetary Fund. London: Cavendish Publishing Limited, 2001.

21. Smith, Steven R. "Social Justice and Disability. Competing Interpretations of the Medical and Social Models": 15-29. In: Kristjana Kristiansen, Simo Vehmas, and Tom Shakespeare, eds. Arguing about Disability. Philosophical Perspectives. London and New York: Routledge, 2009. 
22. Stein, Michael Ashley, and Janet E. Lord. "Future Prospects for the United Nations Convention on the Rights of Persons with Disabilities": 17-40. In: Oddný Mjöll Arnardóttir and Gerard Quinn, eds. The UN Convention on the Rights of Persons with Disabilities. European and Scandinavian Perspectives. Leiden: Martinus Nijhoff Publishers, 2009.

23. Stein, Michael Ashley, and Janet E. Lord. "The Committee on the Rights of Persons with Disabilities": section v. In: Philip Alston and Frédéric Mégret, eds. The United Nations and Human Rights. A Critical Appraisal. Oxford University Press, forthcoming 2018.

24. Stein, Michael Ashley, and Janet E. Lord. "The United Nations Convention on the Rights of Persons with Disabilities as a Vehicle for Social Transformation": 109-122. In: National Monitoring Mechanisms of the Convention on the Rights of Persons with Disabilities. Comisión Nacional de los Derechos Humanos de México, Network of the Americas and Office of the United Nations High Commissioner for Human Rights, 2008.

25. Stein, Michael Ashley, and Penelope J. S. Stein. "Disability, Development, and Human Rights: A Mandate and Framework for International Financial Institutions." UC Davis Law Review 47 (2014): 1231-1278.

26. Steiner, Henry J., Philip Alston, and Ryan Goodman. International Human Rights in Context. Law, Politics, Morals. $3^{\text {rd }}$ edition. New York: Oxford University Press, 2007.

27. Tamang, Parshuram. An Overview of the Principle of Free, Prior and Informed Consent and Indigenous Peoples in International and Domestic Law and Practices. PFII/2004/WS.2/8. New York: United Nations, 17-19 January 2005.

28. Traustadóttir, Rannveig. "Disability Studies, the Social Model and Legal Developments": 3-16. In: Oddný Mjöll Arnardóttir and Gerard Quinn, eds. The UN Convention on the Rights of Persons with Disabilities. European and Scandinavian Perspectives. Leiden: Martinus Nijhoff Publishers, 2009.

29. Trömel, Stefan. "A Personal Perspective on the Drafting History of the United Nations Convention on the Rights of Persons with Disabilities": 115-137. In: Gerard Quinn and Lisa Waddington, eds. European Yearbook of Disability Law. Volume 1. Antwerp, Oxford and Portland: Intersentia, 2009.

30. Vehmas, Simo, Kristjana Kristiansen, and Tom Shakespeare. "Introduction: The Unavoidable Alliance of Disability Studies and Philosophy": 1-11. In: Kristjana Kristiansen, Simo Vehmas, and Tom Shakespeare, eds. Arguing about Disability. Philosophical Perspectives. London and New York: Routledge, 2009. 
31. Zampas, Christina, and Jaime M. Gher. "Abortion as a Human Right International and Regional Standards." Human Rights Law Review 8(2) (2008): 249-294.

\section{LEGAL REFERENCES}

1. Annual Report of the United Nations Special Rapporteur on the Rights and Fundamental Freedoms of Indigenous People. UN Doc. A/HRC/12/34, 15 July 2009.

2. Comprehensive and Integral International Convention to Promote and Protect the Rights and Dignity of Persons with Disabilities. United Nations General Assembly. UN Doc. A/RES/56/168 adopted at the 56 ${ }^{\text {th }}$ Session, 19 December 2001.

3. Concluding Observations of the Committee on the Rights of the Child: Portugal. UN Doc. CRC/C/15/Add.45, 1995.

4. Convention on the Rights of Persons with Disabilities. United Nations General Assembly. UN Doc. A/RES/61/106 adopted at the 61 ${ }^{\text {st }}$ Session, 13 December 2006.

5. $C R P D / C / A R G / C O / 1$. Concluding Observation of the UN Committee on the Rights of Persons with Disabilities.

6. $C R P D / C / A U S / C O / 1$. Concluding Observation of the UN Committee on the Rights of Persons with Disabilities.

7. $C R P D / C / A U T / C O / 1$. Concluding Observation of the UN Committee on the Rights of Persons with Disabilities.

8. $C R P D / C / A Z E / C O / 1$. Concluding Observation of the UN Committee on the Rights of Persons with Disabilities.

9. $C R P D / C / B E L / C O / 1$. Concluding Observation of the UN Committee on the Rights of Persons with Disabilities.

10. $C R P D / C / B R A / C O / 1$. Concluding Observation of the UN Committee on the Rights of Persons with Disabilities.

11. CRPD/C/CRI/CO/1. Concluding Observation of the UN Committee on the Rights of Persons with Disabilities.

12. $C R P D / C / C Z E / C O / 1$. Concluding Observation of the UN Committee on the Rights of Persons with Disabilities.

13. $C R P D / C / D E U / C O / 1$. Concluding Observation of the UN Committee on the Rights of Persons with Disabilities.

14. $C R P D / C / D N K / C O / 1$. Concluding Observation of the UN Committee on the Rights of Persons with Disabilities. 
15. $C R P D / C / E U / C O / 1$. Concluding Observation of the UN Committee on the Rights of Persons with Disabilities.

16. $C R P D / C / G A B / C O / 1$. Concluding Observation of the UN Committee on the Rights of Persons with Disabilities.

17. $C R P D / C / H R V / C O / 1$. Concluding Observation of the UN Committee on the Rights of Persons with Disabilities.

18. CRPD/C/HUN/CO/1. Concluding Observation of the UN Committee on the Rights of Persons with Disabilities.

19. $C R P D / C / K E N / C O / 1$. Concluding Observation of the UN Committee on the Rights of Persons with Disabilities.

20. CRPD/C/MEX/CO/1. Concluding Observation of the UN Committee on the Rights of Persons with Disabilities.

21. $C R P D / C / M N G / C O / 1$. Concluding Observation of the UN Committee on the Rights of Persons with Disabilities.

22. $C R P D / C / M U S / C O / 1$. Concluding Observation of the UN Committee on the Rights of Persons with Disabilities.

23. $C R P D / C / P R Y / C O / 1$. Concluding Observation of the UN Committee on the Rights of Persons with Disabilities.

24. CRPD/C/SWE/CO/1. Concluding Observation of the UN Committee on the Rights of Persons with Disabilities.

25. CRPD/C/TKM/CO/1. Concluding Observation of the UN Committee on the Rights of Persons with Disabilities.

26. CRPD/C/TUN/CO/1. Concluding Observation of the UN Committee on the Rights of Persons with Disabilities.

27. $C R P D / C / U K R / C O / 1$. Concluding Observation of the UN Committee on the Rights of Persons with Disabilities.

28. Declaration on the Rights of Disabled Persons. United Nations General Assembly. UN Doc. A/RES/3447(XXX) adopted at the $30^{\text {th }}$ session, 9 December 1975.

29. Draft General Comment No. 7 - Article 4.3 and 33.3: Participation with Persons with Disabilities in the Implementation and Monitoring of the Convention. UN Committee on the Rights of Persons with Disabilities, 16 March 2018 // http://www.ohchr.org/EN/HRBodies/CRPD/Pages/GC.aspx.

30. General Comment No. 1 - Article 12: Equal Recognition Before the Law. UN Committee on the Rights of Persons with Disabilities. UN Doc. CRPD/C/GC/1 adopted at the $11^{\text {th }}$ Session, April 2014. 
31. General Comment No. 2 - Article 9: Accessibility. UN Committee on the Rights of Persons with Disabilities. UN Doc. CRPD/C/GC/2 adopted at the $11^{\text {th }}$ session, April 2014.

32. General Comment No. 3 - Article 6: Women and Girls with Disabilities. UN Committee on the Rights of Persons with Disabilities. UN Doc. CRPD/C/GC/3 adopted at the $16^{\text {th }}$ Session, August 2016.

33. General Comment No. 5 - Persons with Disabilities. UN Committee on Economic, Social and Cultural Rights. UN Doc. E/1995/22 adopted at the 11th Session, September 1994.

34. ILO Convention No 169 concerning Indigenous and Tribal Peoples in Independent Countries. 1650 UNTS 383, adopted 27 June 1989, entered into force 5 September 1991.

35. Kichwa Indigenous People of Sarayaku v Ecuador. Inter-American Court of Human Rights, 27 June 2012, ser. C, no. 242. // http://corteidh.or.cr/docs/casos/articulos/seriec_245_ing.pdf.

36. Report by the United Nations Special Rapporteur on Disability on the Question of Monitoring //

http://www.un.org/esa/socdev/enable/rights/ahc8docs/ahc8specrep2.doc.

37. Report of the Special Rapporteur on the Rights of Persons with Disabilities on the Right of Persons with Disabilities to Participate in Decision-Making. UN Doc. A/HRC/31/62, 12 January 2016.

38. Shadow Report for the Review of the State of Chile before the Committee on the Rights of Persons with Disabilities in the $15^{\text {th }}$ Session. Corporación Circulo Emancipador de Mujeres y Niñas con Discapacidad de Chile et al. (March 2016) // http://tbinternet.ohchr.org/Treaties/CRPD/Shared\%20Documents/CHL/INT_C RPD_CSS_CHL_23091_E.pdf.

39. Standard Rules on the Equalization of Opportunities for Persons with Disabilities. United Nations General Assembly. UN Doc. A/RES/48/96 adopted at the $48^{\text {th }}$ session, 20 December 1993.

40. Statute of the International Court of Justice. T.S. No. 993, adopted 26 June 1945.

41. Submission to the CRPD Committee on the List of issues in relation to the initial report of Croatia. Croatian Union of Associations of Persons with Disabilities and other contributing DPOs (March 2015) // http://tbinternet.ohchr.org/Treaties/CRPD/Shared\%20Documents/CRO/INT_C RPD_CSS_CRO_19930_E.doc. 
42. Submission to the CRPD Committee on the List of issues in relation to the initial report of the Czech Republic. Czech NGOs and DPOs // http://tbinternet.ohchr.org/Treaties/CRPD/Shared\%20Documents/CZE/INT_C RPD_CSS_CZE_19782_E.pdf.

43. Submission to the CRPD Committee on the List of issues in relation to the initial report of European Union. European Disability Forum (July 2015) // http://tbinternet.ohchr.org/Treaties/CRPD/Shared\%20Documents/EUR/INT_C RPD_CSS_EUR_21276_E.doc.

44. Submission to the CRPD Committee on the List of issues in relation to the initial report of Italy. Italian Disability Foru. (19 July 2016) // http://tbinternet.ohchr.org/Treaties/CRPD/Shared\%20Documents/ITA/INT_C RPD_CSS_ITA_24625_E.doc.

45. Submission to the CRPD Committee on the List of issues in relation to the initial report of Kenya. Disabled People's Organizations in Kenya (June 2015) // http://tbinternet.ohchr.org/Treaties/CRPD/Shared\%20Documents/KEN/INT_C RPD_CSS_KEN_21296_E.docx.

46. Submission to the CRPD Committee on the List of issues in relation to the initial report of Sweden. Swedish Disability Federation // http://tbinternet.ohchr.org/Treaties/CRPD/Shared\%20Documents/SWE/INT_C RPD_NGO_SWE_16818_E.doc.

47. Thematic Advice of the Expert Mechanism on the Rights of Indigenous Peoples. A Compilation (2009-2013). Office of the United Nations High Commissioner for Human Rights.

48. Vienna Convention on the on the Law of Treaties. Signed at Vienna 23 May 1969. 